\title{
EXCURSION TO ILFORD.
}

\author{
SATURday, 25TH March 1893. \\ Director: F. C. J. Spurrelt, F.sq., F.G.S. \\ (Report by the Director.)
}

The party assembled at Ilford station shortly before three o'clock, and leaving the station crossed the railway at the iron foot-bridge, where on either side of the path were seen old pits and those still in work. Those to the east showed the trail, the brick-earth (in which were numerous sun-cracks filled with sand and gravel), and below, the sandy portion of the mammalian beds, which are not now excavated for brick-making. In the upper brick-earth bones were found, as well as the following shells-Limnaa peregra Müll. Planorbis marginatus Drap., Valvata piscinalis Müll., and Pisidium fontinale Drap. The occurrence of all these shells is recorded in Mr. B. B. Woodward's list. No part of this pit showed the bottom.

The railway having been re-crossed east of St. Mary's Church, some smaller excavations were examined to the south east of that church. The party followed the high road into Ilford and turning aside had a glimpse of the great pits at Uphall, whence the greater part of the Brady collection (now in the British Museum) was obtained. These pits are not used at present except for building and market-garden ground. The party then divided, some going to Barking and some to London.

\section{REFERENCES.}

Geological Survey Map, Sheet I S.W. (Drift Edition).

I871. Woodward, H.- "Excursion to Ilford." Proc. Geol. Assoc., vol, ii, p. 273 ; and Record of Excursions, p. 173.

I889. WHITAKER, W.-" The Geology of London," pp. 353, etc.., and 410 etc. Mem. Geol. Survey.

I890. WOODWARD, B. B.- "The Pleistocene Mollusca of the London District." Proc. Gerl. Assoc, vol. xi, pp. 365-37 I, 388.

JuLY, 1893.] 